\title{
https://doi.org/10.46344/JBINO.2021.v10i02.11
}

\section{ROLE OF TRAYOPASTAMBHAS IN MENTAL HEALTH}

\author{
Dr.Durga.E \\ Associate Professor, Ahalia Ayurveda Medical College, Palakkad

\section{Email:drdurgae@gmail.com,}

\begin{abstract}
Ahara,Nidra and Abrahmacarya are the three pillars of life. Supported by these three pillars, the body maintains its strength, colour and growth till the end of life. The purpose of life is to achieve fourfold objectives, viz. virtuous acts (Dharma), acquisition of wealth (Artha), gratification of desire (Kama) and salvation (Moksha). These pursuits can be achieved through austerity, studies, celibacy, fasting and religious vows. Diseases are major impediments to these sacred duties and lone remedy is that of preventing the body from falling ill by achieving a state of positive health. Thus health (Arogya) stands at the very root of achieving the four pursuits of life. The very objective of Ayurveda is achieving healthy status of the body. Both Caraka and Susruta outline similar objectives. They are to maintain the health of the healthy and to cure the disease of the diseased. Caraka in different context states that the object of the science is the maintenance of the equilibrium of the tissue elements (Dhatu). Disequilibrium among tissue elements is postulated as disease and equilibrium as health.
\end{abstract}

Key words: Ahara,Nidra,Abrahmacarya 


\section{Introduction}

Health is a state of wellbeing at all the four planes of life, viz. Soma, senses, psyche and the spirit. Balanced state of the constituents of body (Dosha, Dhatu, Mala and Agnil and satisfaction or pleasure of senses, mind and the soul constitute health.

\section{Ahara}

The individual is no longer healthy unless he receives a healthy food. Hence a proper selection of food is also inevitable to drive out the susceptibility of disease. In modern science they only consider the quantitative values in the body like electrolyte, fat, proteins, iron etc.in percentage concerned with the maintenance of health. As a feedback, only they advices various restriction in food intake. Relevant theory regarding this is a famous one that 'A healthy mind dell in a healthy body'. Meanwhile Ayurvedic treatises provide a vast collection of information regarding the action of food influencing mind. They have explored deeply along the various action by studying Rasa, Guna, Veerya, Vipaka,Prabhava etc. In fact, Ayurveda Considers the body including the faculties as well as mind sets substratum for every disease. There is close relation between psyche and soma and so the psychosomatic concept is much appreciated. The body humors in their normalcy perform much psychological function as well.

Chandogya Upanisad links the origin of mind with food and states that the tenuous (subtlest)portion of food becomes the mind, the basis of the socalled physical nature of mind.
Annamasitam tredha Vidheeyate tasya ya stavishto dhatu tat pureesham bhavati,somadhyamastanmamsam, YO anishtastanmana

Annamayath hi Soumya manah. Chandogyopanisad again emphasizes the relation between the food and mind. The mind is what we eat and a food that is pure results in a clean state of mind.

Ahara shudhou Satva Shuddhi,Satva Shudhou Dhruva Smriti

A clean mind has memory which transcends many births. This very verse probably is the basis for Gita's classification of food into Satvika (pure), Rajasika (pungent) and Tamasika (impure) varieties.In Bhagavad Geetha some references can be seen accessible to the same theory. From Satva results knowledge, from Rajas only greed and from Thamas delusion and ignorance itself.

\section{Satvika food}

Normally they like the foods that augment life energy, strength, health, happiness, joy and which are savory, nourishing and agreeable. In Ayurveda the fourfold type of food mentioned should possess the above qualities. For demonstration foods like milk ghee, fresh and sweet fruits can be included in this Class.

\section{Rajasa food}

Rajas itself is to be of the nature of passion the source of desire and attachment. It prompts the self by attachment of action. 
The foods that are very pungent, sour, hot, saltiest, dry and burning are liked by Rajasa and it will be conducive to pain grief and disease. Generally, the food habits of population are going in such a way. Consequently, from the society itself a lot of live examples like evil acts, quarrels, and impatience suicidal and homicidal tendency etc. are vividly common.

\section{Thamasa food}

Thamas to be born of ignorance and deluding all embodied being it binds through inadvertence, laziness and inactivity. The food cooked three or more hours before i.e., which has become cold, worthless, from which the essence has gone, putrid, foul smelling, the balance after somebody's use, not good for intellect is liked by Thamasik people

As a part of time saving, the preservation and further use of cooked food is common now. Ayurveda also consider it as toxin and harmful for body and mind. Food preserved in fridges, cooked tin foods, alcoholic and non-alcoholic beverages belong to this category. Ucchishta food clearly indicates the possibility of contamination of various microbes.

\section{Rules for taking food:}

Healthy individuals as well as the patients should observe the following, even while using such of the food articles as are most wholesome by nature. One should eat only that food in proper quantity which is hot, unctuous and not contradictory in potency and that too, after the digestion of the previous meal. Food should be taken in proper place equipped with all the accessories, without talking and laughing, with concentration of mind and paying due regard to oneself.

\section{Right time for food intake}

When faeces and urine are excreted, Hridaya becomes clear,Doshas traverse in their right pathways, belching becomes clear, hunger begins and Vata functions properly, digestive power increases, the body becomes light and capable of perceiving the senses; food is to be taken, as it is the right time scientifically recommended for food intake.

\section{Nidra}

Sleep has its existence since the creation of living beings in the universe. Ayurveda consider sleep as one of the three supports of life. The other is Ahara and Brahmacharya.

Thraya Upasthambha ithyahara swapno brahmacharyamithi

A life, which is supported by these 3, wellobserved factors, be endowed with strength, complexion and a full-term life span. Sleep is also included in the 14 natural urges, which are not permissible to be suppressed as they may cause severe pathological conditions.

\section{Cause of sleep}

Thama kaphabhyam nidra syat According to Ayurveda, the prime factor producing sleep is Thamas and the accompanying biological humor is

Kapha.

Over a day's work when the mind, sensory and motor organs become exhausted, they dissociate from the 
objects, then the individual sleeps. The channels of consciousness of which purity keeps us alert, become clogged with Thamas and Kapha, which distort the acuity of mind compelling to relieve from its objects, necessarily wants a relaxation, that is sleep.

\section{Thamas}

All phenomena in the universe are bound to obey a natural rule, Srishti,Sthithi and Samhara, which are affected by three Mahagunas Satva,Raja and Thama. The nature's creation and manifestation are referred to as Satva. The nature organizing and activating phase can be called as Rajas and when the purpose of this stage in complete then the destructive phase which is called Thamas which brings to an end. The influence of these Thrigunas is universal. The same Gunas that governs the universe regulate our mind too.Satva is the quality for happiness, balance and study of mind. Rajas and Thamas are considered as Manodoshas, Rajas brings about activity, change and imbalance of mind, while Thamas literally means darkness, is the quality of dullness, darkness and inertia. Thamas brings about ignorance and delusion in the mind and promotes sleep and loss of awareness.

\section{Role of Thamas and Kapha in sleep}

Among the 3 biological humors Vata, Pitta and Kapha,Kapha is responsible for the induction of sleep.Kapha is made up of Prithvi and Ap mahabhootha which are heavy and the properties of Kapha include heaviness, stability etc. Nidra is occurring due to the increase of Kapha in the body and it has been mentioned as a symptom in Kapha Vriddhi.
Sleep is usually occurring at night. Night is also Thamasik (dark). The darkness increases the Thamas in human beings based on the principle 'Vriddhi Samanai Sarvesham'. In Ashtanga Samgraha Vagbhata says that sleep is Thamasik in origin. (Thamomoola) and Thamasik in constitution (Thamomayi) and has its existence from the origin of this universe itself. Increase in Kapha and Rasadi dhatu constitutes sleep.

Lokadi sarga prabhavo thamomoola thamomayi Bahulyat thamaso rathrau nidra prayena jayate Sleshmavrutheshu dosheshu sramathuparatheshu chalndriyeshu swakarmebhyo nidra visathi dehinam(A.H.Su 9)

Children sleeps more due to the predominance of Kapha in their body and in old age Kapha kshaya and Vata Vridhi induce sleeplessness. After a heavy meal, people feel sleepy due to the increase of Kapha and Rasadhatu in the body.People, predominantly having Kapha Prakruthi, sleep more than those who have the other two Prakruthis.

Sleep according to Susrutha Samhitha Susrutha had mentioned the relation of heart and sleep.In his view sleep is the illusive energy of God and it is natural. Susrutha consider heart as the seat of consciousness (Chethanastana). He compares heart to an inverted lotus, which blooms during wakefulness and contracts during sleep. Pundareekena sadrusam hridayam syad adhomukham Jagrathasthad vikasathi swapnayascha nimeelithi (Su.Sa 4/31)

\section{Utility of sleep}

Even though Ahara, sleep and sexual contact are the three pillars of life, these factors are to be used with discrimination and their excessiveness or in sufficiency 
will cause disease. Hence Acharya has told

'Yuktya Nishevithi'.

Ayurvedic treatises and advocates various norms for practicing sleep in proper manner.They even hold that sleep is the root cause of pleasure pain, nourishment, emaciation strength, weakness, fertility impotency, knowledge, ignorance, lifeand death.These two kinds of positive and negative results can be brought about by proper and improper nidra itself.One should sleep in time for the required period, lest we may fall victim to diseases.

Types of sleep

Ayurvedic Treatises classify sleep as follows

1. Caused by Tamas

2. Caused by Kapha

3. Caused by Fatigue of Mind and body

4. Sleep in terminal stage

5. Pathological sleep

6. Nocturnal sleep

7. Day time sleep

Of them day sleep is caused by the increase of Thamas and Kapha or by fatigue.Generally daytime sleep is not appreciated in Ayurveda due to its deleterious nature towards health, as it is unduly increase Kapha. Keeping awake in night is considered as Rooksha and daytime sleep is unctuous.

Sleep has a therapeutic value in emaciation. During summer daytime sleep is permitted to all, mainly due to the decrease in the length of night. But if a healthy person resorts to day sleep during other seasons there may be aggravation of Kapha and Pitta. In certain pathological conditions such as poisoning even night sleep itself is contra indicated.The sleep caused by the nature of night is considered the best of this classification. This is considered as Bhoothadhathri-means it is like a mother who nurses the child. Likewise, the sleep nurses all the living beings for bestowing health.

The other one, Thamobhava sleep caused by the accumulation of Thamas, is the cause of all sinful acts or the cause of adharma. The reason is thamas causes excessive sleep, by which the individual is unable to perform the virtuous acts, so he subjects himself to sinful behavior. The other all sleeps are considered as pathological, like sleep in sannipathika jwara, become Rishta (deadly prognostic sign) of the disease.

\section{Abrahmacarya}

Abrahmacarya means proper Gramya dharma. There are so many healthy aspects in Ayurveda regarding Gramya dharma.Woman who does not take supine position during coitus, menstruating, not lovable, who has indisposed customs, whose genitalia is unhygienic and abnormal, who is either too obese or too emaciated, pregnant woman, woman other than one's own wife and woman who observes vow are to be excluded from coitus. Teacher's abode, place of worship, royal palace, monastery, burial ground, gallows, courtyard, water reservoirs and cross roads should not be selected for coitus. Copulation on full or new moon days and during day time is restricted. Practices such as sexual perversions and thrashing the head and heart during copulation 
are also not desirable. One who has eaten too much food, coward, one who is hungry, one who is in awkward position, who is thirsty, young children, the aged, one who has other urges to satisfy and the sick are restricted from sexual intercourse. After sumptuously taking drugs which increase virility, one can have sexual intercourse till satisfaction in the Ritus of Hemantha and Sisira, once in three days in Vasanta and Sarat ritus and once in fifteen days in Varsha and Grishma ritus. Sexual intercourse in undesirable ways can lead to Bhrama,Klama,Urusada, decrease in strength, virility, weakness of sense organs and early death. One who indulges in sexual intercourse in a controlled manner remains young for a long time with high memory power, intellectual ability, long life, health, nourishment, high perceptive power of senses, fame and strength. Taking bath, anointing the body, exposure to cool breeze, eating sweets, drinking cold water, milk, meat soup, green gram soup and beverages such as Sura and Prasanna can be had after sex. Thereafter sleep can also be had. This helps in regaining the vitality instantly.

\section{Discussion and Conclusion}

Ayurveda advocates health not only as the fitness of physique but also as the wellbeing of soul, mind and faculties. So, the persons who prefer the attainment of the goal should follow the advice of this health science not only to cure the disease but also for the prevention of psychological and somatic miseries. Shortly the way to pure knowledge is through a clear mind and the same clear food itself. Ahara Suddhai Satva Suddhi Satva Suddhai Dhruvo Smruthim.The proper observance of the three aspects of food, sleep and sex will support the body just like pillars supporting a building.

\section{References}

1.Ahuja Niraj, A short text book of psychiatry, Jaypee brothers' medical publishers, $6^{\text {th }}$ edition (2006) New Delhi

2.Srikantha Murthy K.R,Ashtanga hrdayam,(2017),Chowkhamba

Krishnadas academy, Varanasi vol.1-3

3.Bhagavad Gita,Dr.Leela devi, Dronacarya publications, Kerala.

4. Sharma, R. K and Bhagvan Dash, Charakasamhita (Eng.Translation) vol. 1 to

5. Choukamba Sanskrit Series Office, Varanasi,5.Murthy, A.R.V.\&Singh R.H. (2009): Rationale of Ayurvedic Psychiatry, Chaukhambha orientalia Varanasi. 